NBER WORKING PAPER SERIES

\title{
ALTERNATIVES TO THE CURRENT MAXIMUM \\ TAX ON EARNED INCOME
}

Lawrence B. Lindsey

Working Paper No. 822

NATIONAL BUREAU OF ECONOMIC RESEARCH

1050 Massachusetts Avenue

Cambridge MA 02138

December 1981

This paper was presented at the NBER Conference on Behavioral

Simulation Methods in Tax Policy Analysis, January 25-27, 1981, Palm Beach. I am deeply grateful for the help of Martin Feldstein, Richard Musgrave and Daniel Feenberg. Their comments and criticisms were invaluable. I am also thankful to Jerry Hausman for his suggestions on functional form. The research reported here is part of the NBER's research program in Taxation and project in Tax Simulation. Any opinions expressed are those of the author and not those of the National Bureau of Economic Research. 
Alternatives to the Current Maximum Tax on Earned Income

\section{ABSTRACT}

The Maximum Tax on Personal Service Income was intended to reduce the maximum marginal tax rate on earned income to 50 percent. In general it did not achieve this result, although it did lower marginal tax rates on both earned and unearned income.

This paper considers the effect of different tax rate structures on the total tax revenue collected from high income taxpayers. The sensitivity of tax avoidance practices to marginal tax rates is estimated using four different specifications. These estimates are then combined with plausible parameter values for income and substitution effects in the supply of labor to produce a range of elasticities of taxable income with respect to tax rates. The NBER Taxsim model is then used to estimate the effects of different rate structures on tax revenue.

Lawrence B. Lindsey

National Bureau of Economic Research 1050 Massachusetts Ave.

Cambridge MA 02138 
NBER CONFERENCE

Papers Available from the Conference on SIMULATION METHODS IN TAX POLICY ANALYSIS*

Palm Beach, Florida

Paper

January 25-27, 1981

Number

WP 497 "Alternative Tax Treatments of the Family: Simulation Methodology and Results," by Daniel Feenberg and Harvey S. Rosen

WP 788 "Stochastic Problems in the Simulation of Labor Supply," by Jerry Hausman

WP 822 "Alternatives to the Current Maximum Tax on Earned Income," by Lawrence B. Lindsey

"The Distribution of Gains and Iosses from Changes in the max Treatment of Housing," by Mervyn King

WP 682 "Simulating Nonlinear Tax Rules and Nonstandard Behavior: An Application to the Tax Treatment of Charitable Contributions," by Martin Feldstein and Lawrence B. Lindsey

WP 798 "Issues in the Taxation of Foreign Source Income," by Daniel Frisch

WP 583 "Modeling Alternative Solutions to the Long-Run Social Security Funding Problem," by Michael Boskin, Marcy Avrin, and Kenneth Cone

"Domestic Tax Policy and the Foreign Sector: The Importance of Alternative Foreign Sector Formulations to Results from a General Fquilibrium Tax Analysis Model," by Lawrence Goulder, John Shoven, and John Whalley

WP 673 "A Reexamination of Tax Distortions in General Equilibrium Models," by Don Fullerton and Roger Gordon

WP 799 "A General Equilibrium Model of Taxation with Endogenous Financial Behavior," by Joel Slemrod

WP 681 "Alternative Tax Rules and Personal Savings Incentives: Microeconomic Data and Behavioral Simulations," by Martin Feldstein and Daniel Feenberg

WP 729 "National Savings, Economic Welfare, and the Structure of Taxation," by Alan Auerbach and Laurence Kotlikoff

WP 757 "Tax Reform and Corporate Investment: A Micro-Econometric Simulation Study," by Michael Salinger and Lawrence Summers

*It is expected that the papers resulting from this conference will be published in a volume edited by Martin Feldstein.

Copies of these conference papers may be obtained by sending $\$ 1.50$ per copy to Conference Papers, NBER, 1050 Massachusetts Avenue, Cambridge, MA 02138. Please make checks payable to National Bureau of Economic Research. Advance payment is required on orders totaling less than $\$ 10.00$ 
The Breakers, Palm Beach

January $25-27,1981$

Name

Henry J. Aaron

Alan J. Auerbach

Martin J. Pailey

Michael J. Boskin

Daniel R. Feenberg

Martin Feldstein

Daniel J. Frisch

Don Fullerton

Harvey Galper

Roger H. Cordon

lawrence H. Goulder

David G. Hartman

Jerry A. Hausman

James J. Heckman

Patric Hendershott

Thomas O. Horst

Mervyn A. King

Laurence J. Kotlikoff

Lawrence B. Iindsey

Charles E. Mclure, Jr.

Peter Mieszkowski

Joseph J. Minarik

Richard A. Musgrave

Joseph A. Pechman

Michael Salinger

Robert J. Shiller

John B. Shoven

Joel Slemrod

Joseph E. Stiglitz

Lawrence H. Summers

John Whalley

David Wise

\section{Affiliation}

The Brookings Institution

Ha rvard University

University of Maryland

Stanford University

National Bureau of Fconomic Research

Harvard University and NBFR

University of Washington

Princeton University

U.S. Department of the Treasury

Bell Iaboratories

Stanford University

Harvard University

Massachusetts Institute of Technology

Unversity of Chicago

Purdue University

U.S. Department of the Treasury

University of Birmingham, Fngland

Yale University

Harvard University

National Bureau of Economic Research

University of Houston

The Brookings Institution

Harvard University of the University of California at Santa Cruz

The Brookings Institution

Massachusetts Institute of Technology

University of Pennsylvania

Stanford University

University of Minnesota

Princeton University

Massachusetts Institute of Technology

University of Western Ontario

Harvard University 


\section{Introduction}

The Maximum Tax on Personal Service Income, passed as a part of the Tax Reform Act of 1969, provides a tax reduction to taxpayers with substantial earned income. However it does not, as is widely assumed, place a 50 percent limit on the rate at which earned income is taxed. In an earlier paper I showed that the vast majority of high income taxpayers still face marginal tax rates on earned income in excess of 50 percent.

This paper considers alternatives to the current Maximum Tax rules which would be more effective at setting a 50 percent ceiling on the rate at which earned income is taxed. Particular attention is paid to the behavioral response of taxpayers facied with a change in the tax rules.

The simulations contained in this paper are made with the National Bureau of Economic Research TAXSIM model. This model bases its calculations on the 1977 Tax Model file provided by the Internal Revenue Service. This data file contains a stratified random sample of individual tax returns; a random sample of 7703 of these returns was used for this paper.

The data have been aged to reflect 1981 dollar amounts. TAXSIM does this automatically by. increasing all dollar items by the percent increase in personal service income between the two years. A further adjustment is made to the number of returns in each income class. The TAXSIM estimates of total revenue are within 2 percent of Department of Treasury revenue estimates for any given tax year.

Four alternatives to the present law are considered. Two of these involve a rewriting of the existing Maximum Tax rules to more effectively limit the top earned income tax rate to 50 percent. These alterations as well as existing law create complicated non-linearities in the tax schedule. The TAXSIM model is 
designed to generate precise marginal tax rates for both earned and unearned income to take account of these complexities. The third alternative involves a change in the existing statutory rate schedule to make the top tax rate 50 percent on all income. The fourth alternative considered is abolition of the existing Maximum Tax altogether and application of the current rate schedule to all income regaŕdiless of source.

The methodọlogical emphasis of this paper is on simulating the behavioral response of taxpayers to changes in the tax law. Two types of behavior are considered: changes in effort and change in tax avoidance. Although a well established literature exists on the effect of tax rates on labor supply, most of the studies do not include the affluent, the people affected by the reforms considered in this paper. Therefore a range of parameter values for the effects of price and income on effort has been used. The literature on tax avoidance behavior is not ${ }^{\text {well }}$ established. I present an empirical estimation of this behavior and am conducting further researchion this topic. I use this estimated value as well aș a value half as great as estimated and a parameter implying no avoidance behavior. The reader is free to make judgements based upon his or her expectations of the actual parameters.

Section 1 examines the current Maximum Tax law and the reasons for its failure to set a top rate on earned income of 50 percent. Section 2 considers alternative tax. rules and their revenue cost in the absence of a behavioral response. The excess burden placed on earned income by the different rules is also presented in this section. Section 3 discusses the techniques used in simulating taxpayer response to alternative tax rules. Section 4 presents the results based on a range of paramater values for the behavioral model. 
1. The Existing Maximum Tax Provision

Under existing law a taxpayer qualifying ${ }^{2}$ for the maximum tax provision is allowed to subtract from what his or her tax liability otherwise would have been the difference between the ordinary tax liability on Farned Taxable Income and what that liability would have been if a 50 percent top rate were imposed. Figure 1 illustrates the provision. Without the Maximum Tax the taxpayer's liability would have been the sum of areas $X, Y$, and $Z$. The taxpayer is allowed to subtract the difference between the ordinary liability on Earned Taxable Income (areas $X$ and $Y$ ) and what the liability would have been if a 50 percent rate were imposed $(\operatorname{area} x)$. In short, the taxpayer receives a tax reduction equal to area $Y$ and pays tax equal to areas $X$ and $Z$. The tax due on unearned income (area $Z$ ) is unaffected by this rule.

However, this is not equivalent to a maximum rate on earned income of 50 percent. Consider what happens if the taxpayer earns another dollar of taxable income. Without the Maximum Tax provision he or she would pay B percent on this dollar. The Maximum Tax provision reduces the tax rate by the difference between what it would have been if the taxpayer had only earned income, A percent, and 50 percent, or a tax rate reduction of (A-50) percent. Therefore even with the Maximum Tax, the tax rate on earned income is $(B-A+50)$ percent. This rate will exceed 50 percent unless B percent equals A percent. Only taxpayers with very large earned income, so that both $B$ and $A$ equal the statutory limit of 70 percent, and taxpayers with little or no unearned income are in this situation. A second complication in the Maximum Tax law which increases the marginal tax rate on earned income above 50 percent is that only a fraction of earned income is treated as Earned Taxable Income for tax purposes. The remainder is taxed at the unearned income rate. If we define " $F$ " as the fraction of earned 


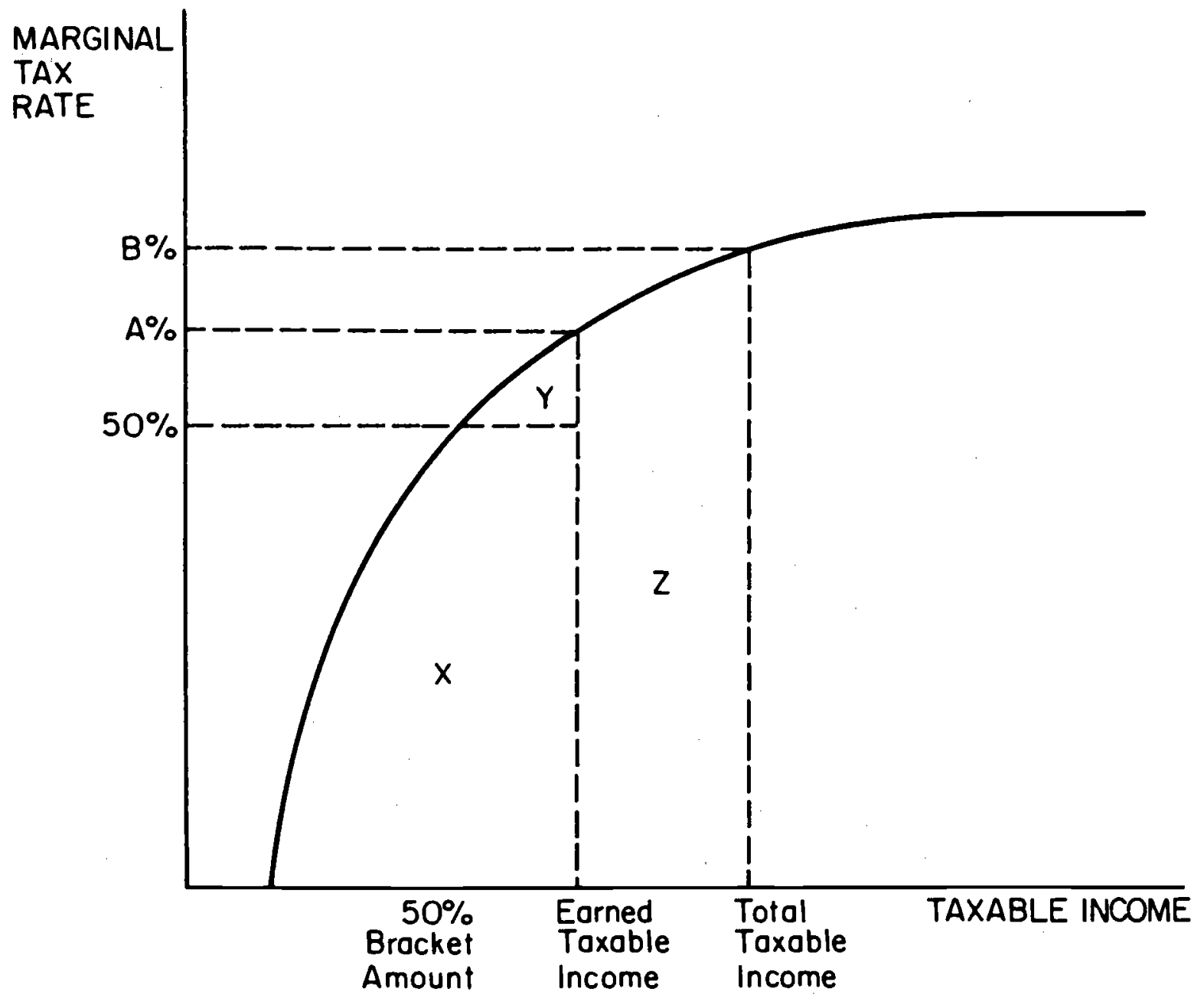


income treated as Farned Taxable Income by the Maximum Tax provision, the marginal tax rate on: earned income becomes:

$$
F x(B-A+50) \text { percent }+(1-F) \times B \text { percent }
$$

It is clear that this rate is in excess of 50 percent as $B>A>50$. Under existing law " $F$ " can be computed as:

$$
\frac{\text { TAXINC }}{A G I}+\frac{\text { PSINC }}{A G I}-\frac{\text { TAXINC }}{A G I} \times \frac{\text { PSINC }}{A G I}
$$

where TAXINC is taxable income

PSINC is Personal Service Income

AGI is Adjusted Gross Income

The reason for this fraction is that deductions must be apportioned between earned and unearned income. The current law apportions deductions to earned income according to the share of earned income in total income. The fraction of each dollar treated as earned income rises as deductions decline as a share of AGI (taxable income rises as a share of $A G I$ ) and also rises as earned income becomes a greater share of AGI.

In summary, the current Maximum Tax law fails to establish a maximum rate on earned income for two reasons. First, the tax rate on Farned Taxable Income $(B-A+50)$ percent depends upon the tax rate levied on the total amount of income received ( $B$ ) percent. Second, only a fraction of earned income is treated as earned for tax purposes. In order to achieve a maximum tax rate of 50 percent, the tax rate on Farned Taxable Income must be independent of $B$ and thus independent of the total amount of income received and the fraction of earned income treated as Earned Taxable Income must be set at unity. 
2. Alternative Tax Rules'

As noted in the preceding section an effective 50 percent ceiling on the tax rate on earned income requires two features: a tax rate on earned income independent of total income received and full treatment of earned income as Earned Taxable Income. Figures 2 and 3 show how the first feature may be achieved.

Figure 2 illustrates a taxpayer with unearned income in excess of the 50 percent bracket;amount. His or her tax liability (shown by the shaded area) would equal to what would ordinarily be owed on unearned income if that were all the income received plus 50 percent of earned income. Note that the tax rate on earned income ( 50 percent) would be independent of the amount of earned or unearned income received, unlike present law.

Figure 3 ililustrates a taxpayer with unearned income less than the 50 percent bracket amount. The shaded region shows the tax liability would be equal to what would be owed if a 50 percent top bracket were in effect. Again the tax rate on earned income would be 50 percent regardless of the amount of earned or unearned income received.

The change in tax rules represented by Figures 2 and 3 might be termed a reversal of the "stacking" order. In Figure 1, unearned income was stacked on top of earned income for the Maximum Tax provision. In Figures 2 and 3 earned income is stacked on top of unearned income. It is essential that the type of income subject to a maximum rate be stacked on top if the top rate is to be effective. Otherwise the tax rate on the favored income source is dependent on the total amount of income received.

It should be noted that the reversal of the stacking order also lowers the marginal tax rate on unearned income. This is because the unearned tax rate is 


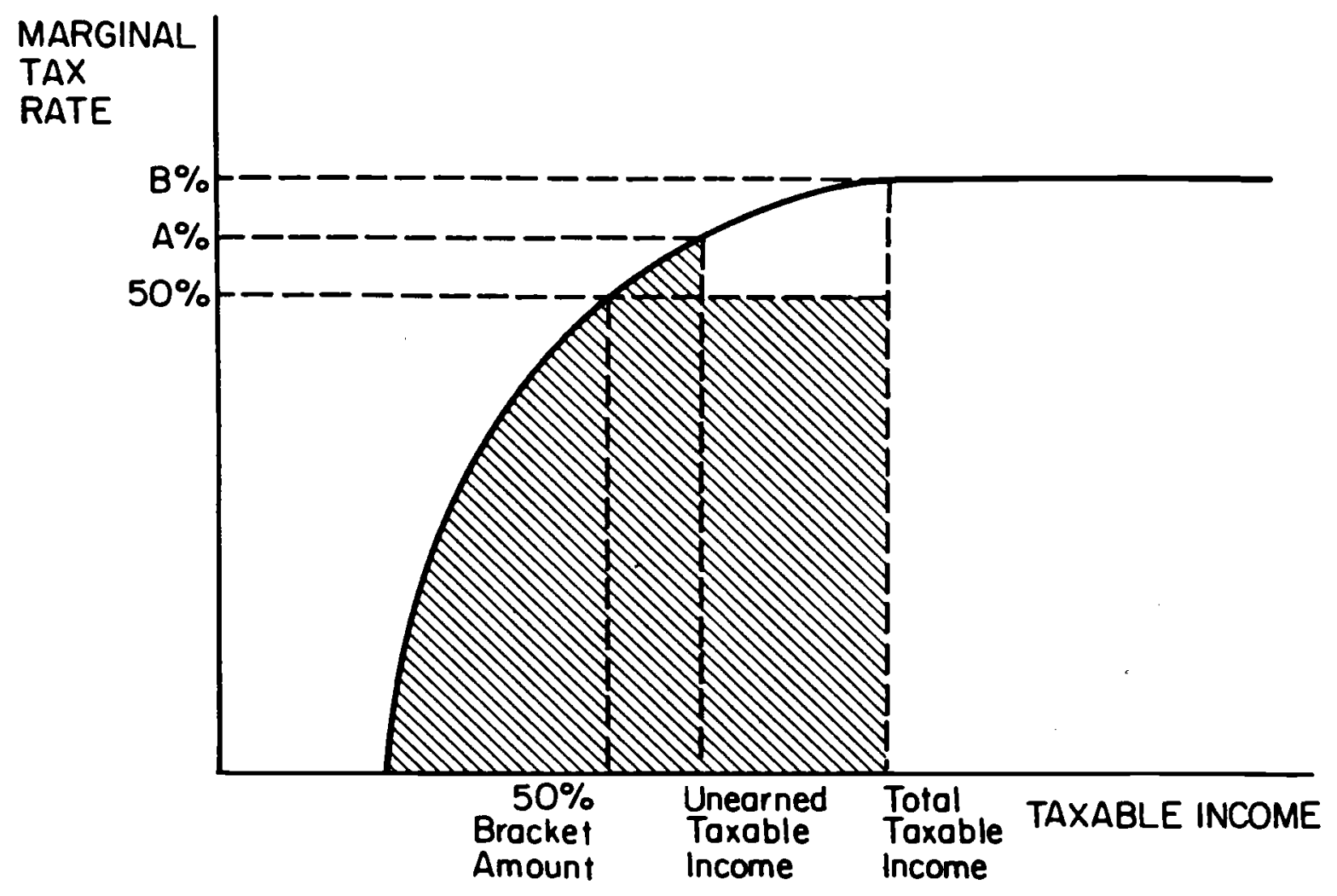




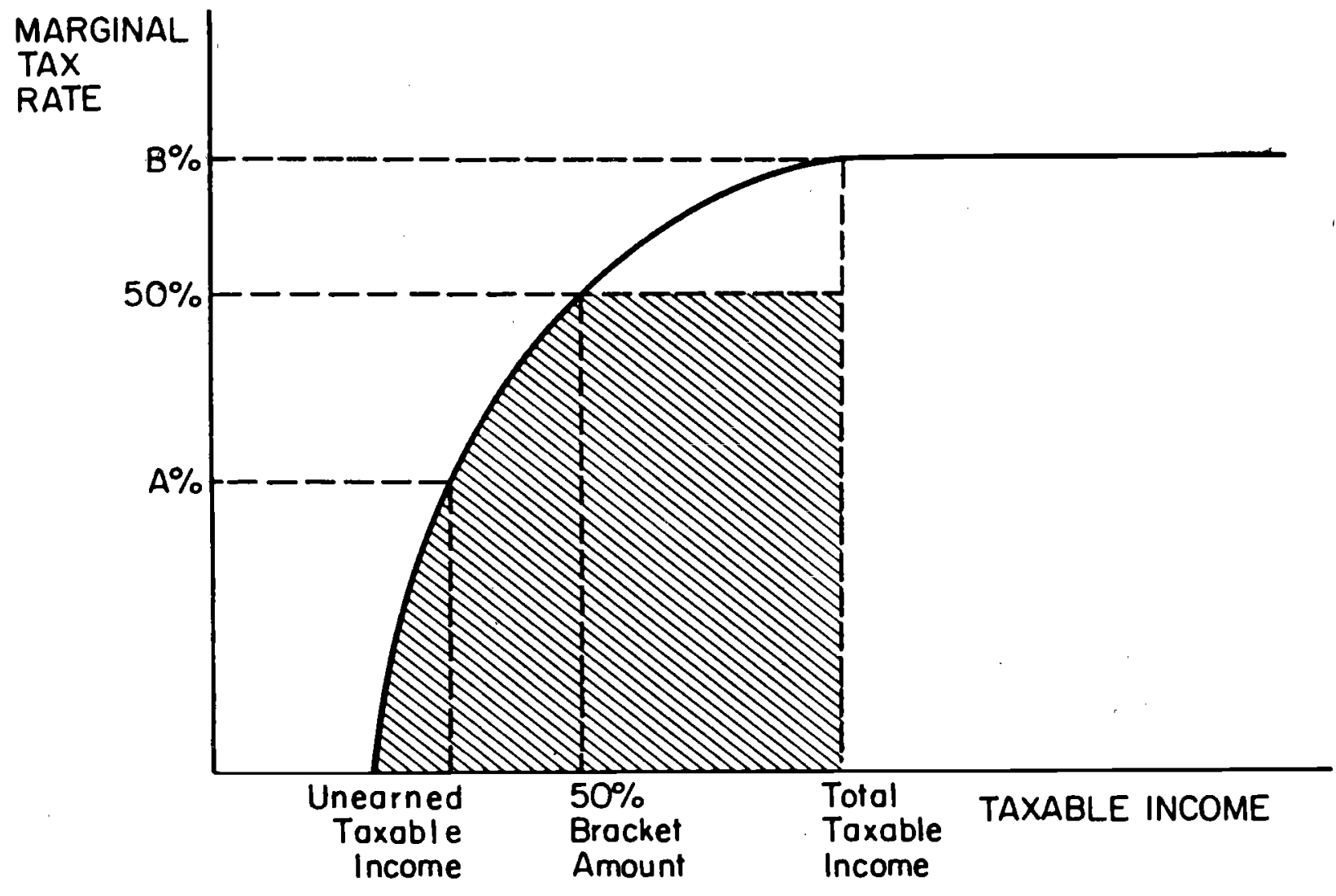


also independent of the total amount of income received. Reductions in both the earned and unearned rates mast be considered when evaluating the behavioral effects of a change in the law.

The second feature which must be changed in order to have an effective 50 percent maximum tax rate is the allocation of deductions from adjusted gross income. The current apportionment based on the share of AGI which is earned causes only a portion of additional earned income to be treated as earned for tax purposes. 3 In order for all earned income to be treated as earned for tax purposes, deductions must be subtracted either entirely from earned income or entirely for unearned income. Of course the alternative chosen will affect the after tax cost of the deduction since the earned and unearned rates may be different. Applying all deductions to unearned income reduces their cost by the rate applicable, to unearned income. As this rate is at least as great as the rate applied to earned income the cost of this option in revenue is greater. Similarly, the behavioral response to such a change would be different. If any tax avoidance takkes place it will reduce the tax liability by the higher unearned income tax rate for each dollar of taxable income avoided. This will be considered in Section 3.

The alternalive of applying all deductions to earned income effectively levies a tax equal to the difference between the unearned and earned rates on all deductions made. While it is clear that this will cost less in revenue it also raises the price of many "merit" goods to Maximum Tax payers.

The option of applying deductions to earned income (REFORM - E) and applying deductions to unearned income (REFORM - U) are compared with abolishing the Maximum Tax and lowering the maximum rate to 50 percent on all income in the charts below. 
Table 2.1 shows the distribution of marginal tax rates on earned income under the five different sets of tax rules. The percentages shown are of the estimated 2,720,000 taxpayers who would have faced marginal tax rates on earned income of 50 percent or greater had there been no Maximum Tax. Note that the current Maximum Tax provision lowers the earned income rate to 50 percent or less for only 7 percent of these taxpayers. One third of these taxpayers has a marginal tax rate on earned income greater than 54 percent. On the other hand, reducing the top bracket to 50 percent will lower all marginal rates to under 52 percent; the same will be accomplished for 95 percent of these taxpayers by implementing REFORM-U. REFORM-E will lower the tax rate on earned income to 52 percent or less for 92 percent of these taxayers.

The reason; that tax rates may be above 50 percent even if that is the top tax bracket involves some of the income constraints of the tax code. For example, the medical deduction is allowed only for expenses in excess of 3 percent of Adjusted Gross Income. As earning another dollar will lower deductions by three cents, taxable income will rise by $\$ 1.03$. At a 50 percent marginal tax rate, the extradollar earned will increase tax liabilities by 51.5 cents. The marginal tax rates on earned income may be lower than 50 percent due to the personal income constraint on retirement contributions.

Table 2.2 shows the distribution of the changes in revenue resulting from a change in the Maximum Tax provision. The current Maximum Tax rule gives about 60 percent of the tax reduction to taxpayers with Adjusted Gross Income above $\$ 200,000$. This compares with 62 percent for a complete reduction in rates to 50 percent, 49 percent for REFORM-U, and 36 percent for REFORM-E.

Table 2.3 compares the excess burden imposed by different tax regimes. The excess burden measure I use is explained in Yitzhaki(1975). This measure 
Table 2.1

DISTRIBUTION OF MARGINAL TAX RATES ON FARNED INCOME

\begin{tabular}{|c|c|c|c|c|c|}
\hline $\begin{array}{l}\text { MARGINAL } \\
\text { RATE }\end{array}$ & $\begin{array}{l}\text { ABOLISH } \\
\text { MAX: TAX }\end{array}$ & $\begin{array}{l}\text { CURRENT } \\
\text { MAX TAX }\end{array}$ & $\begin{array}{l}50 \% \text { TOP } \\
\text { BRACKET }\end{array}$ & $\begin{array}{c}\text { REFORM } \\
\text { "U" }\end{array}$ & $\begin{array}{c}\text { REFORM } \\
\text { "E" }\end{array}$ \\
\hline under 50 & & 0.5 & 5.9 & 4.8 & 1.9 \\
\hline exact 50 & $:$ & 6.2 & 27.0 & 25.1 & 24.3 \\
\hline $50-51$ & $39: 2$ & 47.4 & 38.5 & 38.6 & 39.0 \\
\hline $51-52$ & 1,2 & 12.1 & 28.6 & 26.8 & 25.9 \\
\hline $52-54$ & $!$ & 0.8 & & & \\
\hline $54-56$ & 31.0 & 19.2 & & 2.6 & 3.6 \\
\hline $56-60$ & $7: 5$ & 4.9 & & 0.7 & 1.4 \\
\hline $60-65$ & 11.7 & 5.6 & & 0.8 & 1.9 \\
\hline $65-70$ & 5.1 & 2.2 & & 0.3 & 1.2 \\
\hline over 70 & 4.3 & 1.1 & & 0.3 & 0.8 \\
\hline
\end{tabular}

Percentages reflect the share of $2,720,000$ taxpayers who would have had marginal tax rates on earned income of 50 percent or greater if there were no Maximum $\operatorname{Tax}$. 
Table 2.2

AGI CLASS (000)

under 50

$50-100$

$100-200$

$200-500$

$500-1000$

over 1000

AGI CLASS

(000)

under 50

$50-100$

$100-200$

$200-500$

$500-1000$

over 1000

AGI CLASS (000)

under 50

$50-100$

$100-200$

$200-500$

$500-1000$

over 1000
ABOLISH

MAX TAX

4,000

403,000

349,000

79,000

7,000

1,600

ABOLISH

MAX TAX

$+\quad 270$

$+440$

$+3,210$

$+16,600$

$+51,700$

$+151,200$

ABOLISH

MAX TAX

$\begin{array}{rr}+ & 1 \\ + & 177 \\ + & 1120 \\ + & 1311 \\ + & 354 \\ + & 238\end{array}$
$50 \%$ TOP

BRACKET

53,000

780,000

494,000

105,000

10,500

3,400

Average Tax Change

50\% TOP

BRACKET

90
$-\quad 450$

$-2,680$

$-14,500$

$-54,300$

$-246,000$

Total Tax Change

(millions)

50\% TOP

BRACKET

5
$-\quad 351$

- 1324

- 1523

- 570

- 836
REFORM

"U"

8,000

729,000

474,000

100,000

10,000

3,000

REFORM

"U".

- 810

- 500

$-2,030$

$-9,200$

$-22,000$

$-46,000$
REFORM

"E"

$$
\begin{array}{r}
3,800 \\
673,000 \\
407,000 \\
75,000 \\
6,500 \\
1,500
\end{array}
$$

REFORM

"E"

- 1,030

- 470

- 1,800

- 6,900

- 11,000

- 5,500
REFORM

"U"

6
$-\quad 365$

- 962

- 920

- 220

- 138
REFORM

"E"

- 4

- 316

- 733

$-\quad 733$
$-\quad 72$

-72
$-\quad 8$

$-\quad 8$
$-\quad 8$ 
contrasts the taxes actually collected by a labor income tax with what could have been collected with a lump sum tax and left the taxpayer at the same level of utility. The result takes the familiar form:

excess burden $=1 / 2 e_{i} t i^{2} W_{i}$

where $e_{i}$ represents the individual elasticity of labor supply, $t_{i}$ his or her marginal tax rate on earned income and $w_{i}$ labor income. The excess burden is an increasing quadratic function of tax revenue collected. If contrasted with the revenue collected this measure provides a relative efficiency cost of various tax rules. This measure also takes no account of any excess burden placed on capital income.: The $W_{i}$ term reflects only Personal service income.

The calculations assume a labor supply elasticity of 0.1 for all individuals. The reader may chose to substitute a different elasticity for this estimate of " $e_{i}$ " to get a measure of the efficiency of any one tax regime. However, the relative efficiencies of each of the tax changes is unaffected by the choice of elasticity.

As the calculation is a function of the square of the tax rate, a 70 percent rate will level twice the excess burden of a 50 percent rate. Abolishing the maximum tax would involve an increase in revenue with twice the efficiency cost of the next highest alternative. REFORM-E involves a reduction in tax revenue of 1.651 billion, but would be the most efficient reduction from the view of the excess burden on labor income. As a reduction to 50 percent of the top bracket would apply in large part to capital incorne, the efficiency loss is relatively low.' 
$-11-$

Table 2.3

\section{PROPOSAL}

CHANGE IN TAXES

(billions)

BRACKET

ABOLISH

MAX TAX

REFORM

"E"

REFORM

"U"
$-4.599$

CHANGE IN EXCESS BURDEN (billions)

$-0.380$

0.08

$+1.246$

0.39

$-0.289$

0.18

$-1.645$

$-0.368$

0.14

$-2.608$

\section{(1.368}


3. Simulation Methods

This paper concentrates on simulating two different kinds of responses by taxpayers to changes in the llaximum Tax rules: changes in the degree of sacrifice made to work and save and changes in the avoidance of income tax. Well established parameter values for these responses do not exist. The taxpayer makes his or her decisions based upon a number of separate yet interrelated margins: work and leisure, savings and consumption, and receipt of taxable income and avoidance of taxable income.

A. The Effect of Tax Rules on Effort

The effect of a change in tax rules on work effort is the combined result of a substitution or compensated price effect and an income effect. A reduction in marginal tax' rates induces greater effort by raising the after tax wage. However, the resulting tax reduction increases the taxpayer's disposable income producing a countervailing income effect.

Using the Slutsky equation, this may be expressed as

$$
\frac{\delta h}{\delta w}=S_{w w}+h \frac{\delta h}{\delta y}
$$

where $h$ represents labor effort, w the after tax wage and $y$ income. The compensated price effect, $s_{W w}$ is constrained to be non-negative. $\delta \mathrm{h} / \delta \mathrm{y}$ is presumed to be negative.

The labor supply function for individual $i$ can be expressed as:

$h_{i}=k_{i} w_{i} \alpha_{y_{i}}^{\beta}$

where $\alpha$ represents the uncompensated wage elasticity of labor supply and $B$ the income elasticity of labor supply. $k i$ represents the individual's tastes. 
The constant elasticity formulation may be defended for changes of the magnitude concerned here, although this specification is not plausible for extreme values.

The Slutsky relationship may be expressed in terms of elasticities:

$$
\mathrm{S}_{\mathrm{wW}}=\begin{gathered}
\mathrm{h} \\
\vdots
\end{gathered}
$$

Further manipulation produces an expression in terms of the compensated wage elasticity, $\varepsilon_{\mathrm{c}} \cdot$

$$
\varepsilon_{c}=\alpha-\beta \frac{w h}{y}
$$

The taxpayers subject to the options considered in this paper often have substantial non-labor income. The compensated elasticity therefore varies substantially across the sample. wh/y represents the share of labor income in total income. This has a mean value of roughly 0.75 for current Maximum Taxpayers.

Non-labor income affects the labor supply decision by altering the budget constraint between consumption and leisure:

$$
(1-t) L+M=C+(1-t)(L-h)
$$

$L$ represents the taxpayer's endowment and is enumerated in before tax consumption units. C represents consumption and $\mathrm{L}-\mathrm{h}$ leisure. $M$ is a lump sum term which includes both capital income and the lump sum payment implied by the progressive income tax. Hausman has termed this latter component "virtual income".

Figure 4 jḷlustrates how a progressive tax system yields a lump sum term. A worker sacrificing $l_{1}$ hours of leisure works $l_{0}$ tax free and pays a $\operatorname{tax} t_{l}$ on all labor in excess of $1_{0}$. The taxpayer's marginal decision is based on a price of leisure of $\left(1-t_{1}\right)$ but not the full income reduction this would imply if he paid tax on the total labor supplied. He receives an income transfer of $M_{1}=t l_{0}$ aside from the tax paid $t_{1} l_{1}$. The income transfer $M_{2}$ represents $\left(t_{2}-t_{1}\right)(12-10)+t_{21}$; this is the difference between the tax rate paid on the 
FIGURE 4

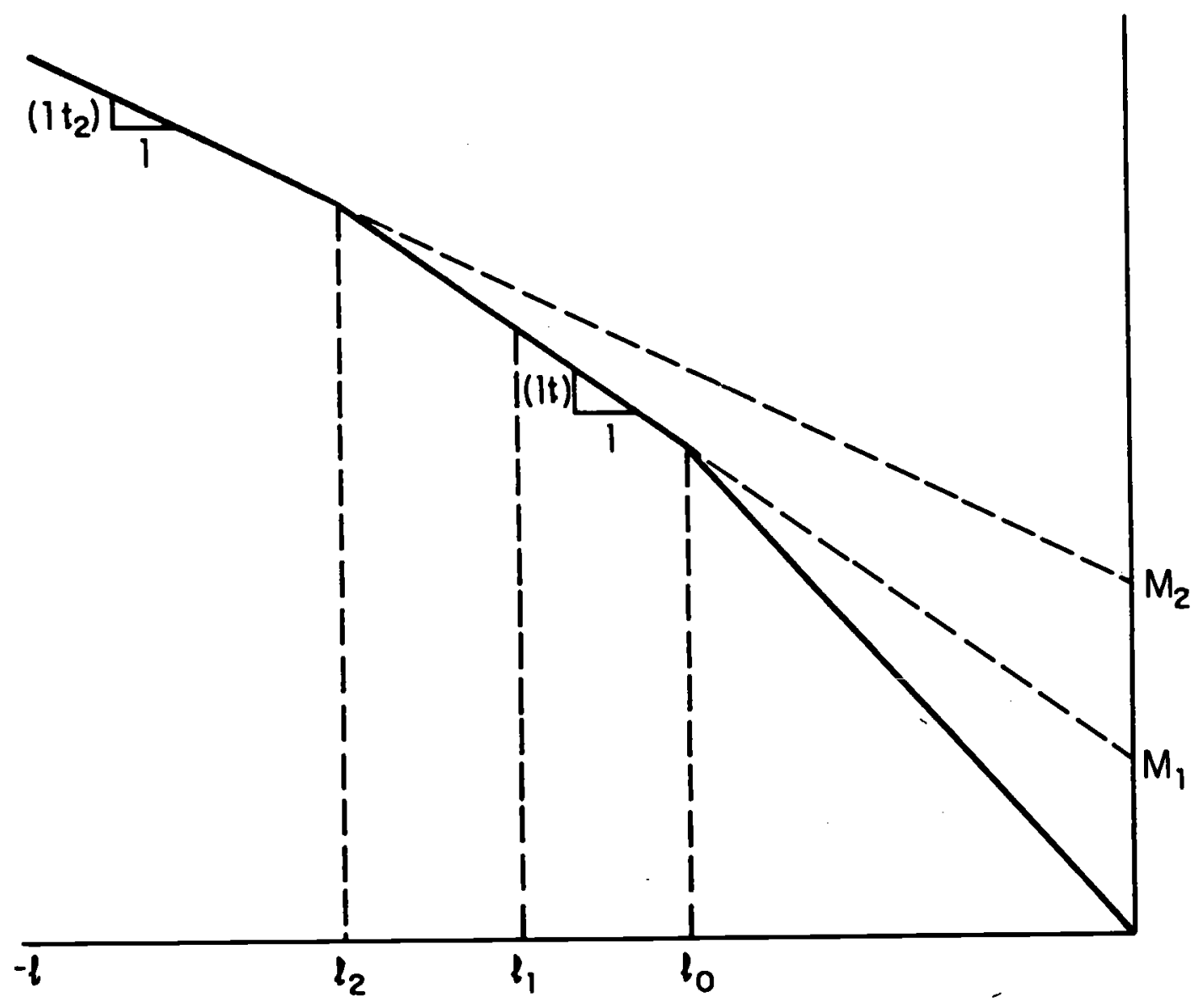


last unit of labor supplied and the tax rate actually paid on infra-marginal units. Note that if the tax rate schedule is known, the income term $M$ is uniquely defined by the taxpayer's last dollar marginal tax rate. Variations of labor supply along any segment, or between any two kinks, does not alter the income term $M$.

The Maximum Tax creates a further complication. The marginal tax rates on earned and uneained income are different, and are altered by different amounts in each of the options considered in this paper. The taxpayer faces a consumption- savings choice as well as a consumption-leisure tradeoff. The change in the tax rate on capital income might well alter this decision. However, the combined price and income effects of the change produce an ambiguous result on a priori grounds. I assume that aggregate capital income is unaffected by the change in the tax rate on either labor or non-labor income. However, the reduction in the tax rate on capital income does increase the taxpayer's virtual income. This will tend to depress the supply of labor by the household.

With the exception of abolishing the existing Maximum Tax, all of the options considered here have a greater effect on the return to capital income than on the return to labor income. The assumption of zero elasticity of capital income to changes in the tax rate is probably an understatement of the response of taxpayers to lower rates and was chosen to minimize predicted revenue changes. Similarly, values which suggest a highly inelastic supply of labor have been chosen for this simulation. Four sets of values have been used: the implied compensated elasticity for a typical Maximum Taxpayer has been computed and is indicated by Table 3.1 .

Empirical studies of the labor supply of prime age males suggest wage elasticities of zero. The households studied in this paper are overwhelmingly married couples and therefore are likely to have labor supplies which are 
Table 3.1

Parameter Values Used in Simulation

Wage Elasticity Income Elasticity Implied Compensated Elasticity

0.

0.

$0.075 i$

0.1
0.

$-0.1$

$-0.1$

$-0.2$
0.

0.075

0.15

0.30

substantially more elastic than this. The parameter values used here imply an elasticity of labor supply only slightly more elastic than that for prime age males.

B. The Fffect of Tax Avoidance

In the above discussion it, was assumed that all income was actually subject to tax. In fact, much income received is not taxed. Tax avoidance may involve donation of income to charitable organizations. It may involve taking advantage of the exclusions available to some forms of capital income. Avoidance also includes tax preferences granted to particular uses of capital or to the purchase of state and local bonds. Nuch farm, rent, and small business income may be avoided by taking advantage of the separately taxed entity for consumption purposes. i formal model of all these avoidance decisions is beyond the scope of this paper. It remains a topic of continuing research, however.

For this paper the avoidance decision is approached at the margin. A utility maximizing taxpayer would allocate his or her resources in order to equate the marginal after tax benefits from each purchase. The marginal dollar expended on avoidance brings benefits equal to the marginal dollar less tax used for ordinary consumption purposes. As a result, the price "p" used above to compute effort is unaffected by the level of tax avoidance. The marginal cost of avoidance also is "p". 
Due to the Maximum Tax, taxpayers face different prices for avoiding labor and non-labor income. The price of some forms of avoidance, preference items, is also increased by the Maximum Tax. This is due to the "poisoning" provision of the laximum Tax law which treats one dollar of labor income as capital income for each dollar; of preference income received. In effect the preferences are taxed at the difference between the unearned income and earned income marginal tax rates, a difference which may be as high as 20 percent. However, preference income comprises only a small portion of income which avoids tax. I therefore have taken the price of avoidance as a simple weighted average of the earned $\left(t_{e}\right)$ and unearned $\left(t_{u}\right)$ marginal tax rates where the weight depends on the share of labor income; in total income, $\tau$.

$$
p=\tau\left(1-t_{e}\right)+(1-\tau)\left(1-t_{u}\right)
$$

It is also; possible that infra-marginal dollars of avoidance cost less than marginal dollars. This would affect the virtual income of the taxpayer in the same way as the non-linear tax schedule affected it. A reduction in marginal tax rates would lower the infra-marginal income taxpayers receive from low-cost avoidance items and therefore raise labor supply. In order to err on the side of conservatism I have ignored the infra-marginal transfer on untaxed income by assuming that all avoidance costs the marginal price.

While the marginal price of avoidance is known, the quantity of income which avoids tax is unknown. I have considered the following relation:

$$
\text { Avodiance }=A(\text { Price, } \text { Income, Tastes) }
$$

I used a sample of 7703 returns from the 1977 Individual Tax Model file, the same sample used in the simulations reported on in section 4. The taxpayer's total income was estimated as his or her potentially taxable income reported in the file. Potential income was calculated by adding retirement contributions, 
capital gains deductions, the dividend exclusion, and reported preference income to Adjusted Gross Income. If the taxpayer reported any Schedule $\mathrm{E}$ loss, it was excluded. Schedule $\mathrm{E}$ gains were unaffected. The standard deduction and personal exemptions for the 1977 tax year were then subtracted as they involve no avoidance behavior by the taxpayer.

Avoidance is calculated as the difference between potentially taxable income and income which is actually taxed. Neither the author nor any reader should consider this a definitive measure. The definition of what should constitute taxable income has concerned such noted economists as Musgrave and Pechman. I do not wish to enter the debate. If anything this estimate probably understates "true" potential income. Interest from state and local bonds is excluded as are unrealized capital gains, imputed rental income and the imputed value of household services. No effort has been made to estimate tax evasion. On the other hand, some might argue that the inclusion of state and local taxes and charitable contributions is inappropriate. As the taxpayers in this study are liable to have substantial capital assets which are not observed, the relationship I estimate probably understates the true effect of price on avoidance.

However, some might argue that much of the estimated avoidance is actually the realization: of long term capital gains. I have therefore defined an alternative income concept which excludes the capital gains deduction from both the income and the avoidance term. Four relationships were estimated:
1) RATIO $_{i}=\alpha+\beta$ FDARAT $_{i}+\varepsilon_{i}$
2) RATIO $_{i}=\alpha+B$ FDARAT $_{i}+\lambda \ln \left(\right.$ INCOME $_{i}+\varepsilon_{i}$
3) RATIO* $_{i}=\alpha+$ B FDARAT* $i+\varepsilon_{i}$
4) RATIO $_{i}=\alpha+\beta$ FDARAT $_{i}+\lambda \ln \left(\operatorname{INCOME}^{*}\right)_{i}+\varepsilon_{i}$ 
RATIO $_{i}$ is the share of potential income which avoids tax, FDARAT 1 is the taxpayer's weighted average of first dollar tax rates on earned and unearned income and INCOIIF is the taxpayer's potential income. The * denotes the alternative concept of avoidance which excludes the capital gains deduction. A first dollar rate was used to minimize possible simultaneity problems. That is, the rate used was the rate which would have applied had the taxpayer avoided tax on only one dollar of income.

There seems no a priori reason why the share of income which avoids tax should vary systematically with income. Inclusion of an income term in equations 2 and 4 is done to test for possible scale economies in avoidance or for the possibility that tax avoidance behavior is associated with being rich aside from the higher marginal tax rates. The results suggest that income is not an important factor.

1) RATIO $=-0.086+0.742$ FDARAT $(0.006)(0.012)$

2) RATIO $=-0.084+0.748$ FDARAT $-0.0004 \ln ($ INCOME) $(0.009)(0.026) \quad(0.0016)$

3) RATIO $^{*}=-0.074+0.686$ FDARAT* $(0.006)(0.011)$

4) RATIO* $=-0.067+0.708$ FDARAT* -0.0016 In(INCOME) $(0.009)(0.024) \quad(0.0015)$

Standard errors are reported below the coefficient. The income coefficient is both small and insignficant. The price term has a highly significant $t$ statistic and all four equations are signicant to the 0.9999 level using an $F$ test. The R-square terms range from 0.329 to 0.341 which is quite reasonable for cross section data. The exclusion of long term capital gains deductions has little effect on the coefficient. 
The usual collinearity of income and the tax rate is substantially reduced by the Maximum Tax. Taxpayers earning from $\$ 60,000$ to $\$ 10,000,000$ may have marginal tax rates of 50 percent while taxpayers within this range may have rates as high as $70 \%$. In fact, the marginal tax rate on earned income falls as earned income rises for Maximum Taxpayers and the rate on unearned income may also fall as unearned income rises. (see Lindsey(1981)). The Maximum Tax provision therefore permits substantial enough variation between rate and income to make estimation possible.

This estimated response of taxpayers to changes in marginal tax rates suggests that 0.7 percent less income will avoid tax for each 1 percent reduction in the marginal tax rate. This paper also presents estimates using a simulated response only half as great, that is an additional 0.35 percent of potential income is subject to tax for each 1 percent reduction in the tax rate. As an example of this effect, consider a married couple with potential income of $\$ 100,000$ of which $\$ 20,000$ is capital income. Their current avoidance price is 44 cents on the dollar ( an average marginal tax rate on earned and unearned income of 56 percent). They avoid taxes on roughly 31 percent of their income. A tax rate reduction to 50 percent would mean an increase in their taxable income of $\$ 4200$, from $\$ 69,000$ to $\$ 73,200$. This is certainly a plausible order of magnitude. The actual simulation procedure uses the taxpayer's actual ratio of taxable income to potential income and adjusts the ratio by the avoidance parameter value times the change in the marginal tax rate.

\section{Combining Behavioral Ef fects}

This behavioral model assumes the taxpayer responds simultaneously to prices on two margins. The share of the taxpayer's income which is avoided is deter- 
mined by a first dollar price based upon his or her potential income. The amount of potential income is determined by a constant elasticity type of response of labor income to the last dollar tax rate on earned income and its corresponding virtual income. But these terms are determined by the share of potential income which avoids tax.

The simultaneous optimizatation of potential income and share which avoids tax is in the following manner: first, the taxpayer's current first and last dollar prices are computed by TAXSIM. Then the first and last dollar prices are computed given the alternative set of Maximum Tax rules assuming no behavioral response by the taxpayer. The difference between the first dollar prices under current law and the alternative law is used to compute a new percentage of potential income which avoids tax.

This new parcentage of avoidance is applied to an unchanged level of potential income to generate a measure of taxable income assuming only the avoidance response. This measure of taxable income is equivalent to assuming that the taxpayer has a zero price and income elasticity of labor supply. Marginal tax rates on earned and unearned income are computed given this new level of taxable income. If these tax rates are the same as the tax rates under current law, no increase in labor supply can be expected.

If these new tax rates are different from current law, a new level of virtual income is computed and a new level of effort results. This new level of effort or potential income may lead to a new level of avoidance if the higher potential income produces a new first dollar tax rate. If not, the old level of avoidance is retained.

The new avoidance measure is used with the new potential income to produce a new level of taxable income. If the marginal tax rates at this level of 
taxable income equal the earlier tax rates, a stable preference decision has been reached. If not, the iteration procedure continues until the new set of tax rates equals an old set of tax rates.

A possible problem with this iterative procedure is the kinked nature of the budget set.: Iteration may produce a result alternatively at a high and a low price. Figure 5 shows such a possibility. The true utility maximizing value for the taxpayer is 'to be on the kink. But, the iterative procedure evaluated at $p_{1}$ will place the taxpayer at $l_{2}$ on the $p_{2}$ segment and evaluation at $p_{2}$ will palce the taxpayer at $l_{1}$ on the $p_{1}$ segment. If this result occurs, the kink between the two segements is automatically chosen. The price and virtual income corresponding to the higher segment, in effect a "next" dollar price, is used for evaluation.

D. Simulation Procedure Differences Among the Options

The two relevant prices, one applying to extra sacrifice, the other to avoidance behavior, depend upon the option considered. For example, the abolition of the maximum tax, or the alternative option of cutting the maximum statutory rate to 50 percent involve equal tax rates on earned and capital income. On the other hand, the existing Maximum Tax and the two reform options may involve different marginal tax rates on earned and unearned income. For these latter two options a weighted average of the earned and unearned tax rates is used to estimate the last dollar price.

The first dollar price, the price of avoidance, is different for the two reform options than for the former options mentioned. If all deductions are applied to earned income, than the price of avoiding a dollar of taxable income is determined by the earned income tax rate. If the deductions are applied to 
FIGURE 5

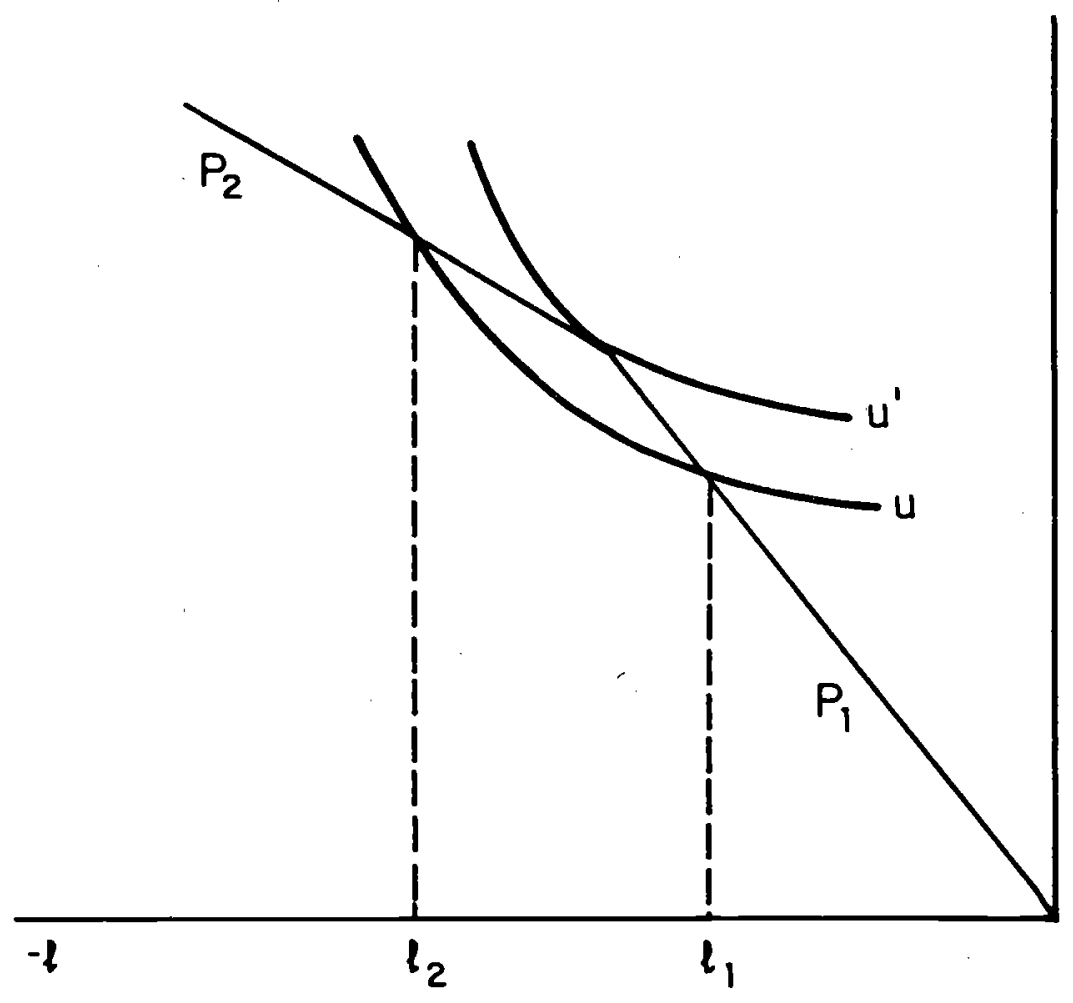


unearned income, then thè price is determined by the unearned income tax rate. The present price of avoidance is a weighted average of the first dollar earned and unearned tax rates.

If deductions are applied to unearned income, then some taxpayers may see a decrease in the price of avoidance. This will lower the share of income which is reported and reduce tax revenue. If on the other hand, deductions are applied to earned income an unambiguous increase in the price of avoidance will result. This will lower the share of potential income which avoids tax and will tend to produce higher revenues.

Lowering the maximum rate to 50 percent on all income also unambiguously increases the price of avoidance thereby increasing taxable income. On the other hand, increases in avoidance will occur among taxpayers currently benefitting from the Maximum Tax if it is abolished. The next section examines the effect of these behavioral changes on Income Tax Revenues. 
4. Results

The results of the simulations are presented in Tables 4.1 through 4.4 . The surprising conclusion one can draw is that it is possible to reduce marginal tax rates and still increase tax revenue. Table 4.1 suggests that the existing Maximum Tax provisions are probably a revenue raiser in that abolishing the Maximum Tax will lead to a decrease in tax revenue. Even at half the estimated value of the avoidance response tax revenues are simulated as decreasing when the rates are increased. Table 4.1 gives the best picture of a labor supply response as the; current laximum Tax yielded a reduction in the marginal tax rate on earned income far greater than any of the other options considered. The greatest response simulated yielded 4.7 billion more in tax revenues from the labor supply effect alone while even the most modest labor supply response yielded nearly 2 billion more in revenue than the no response case.

Even in this case the avoidance response is likely to dominate the labor supply response. If no labor supply response is assumed, 6.6 billion more in revenues was raised by establishing the Maximum Tax. The avoidance response is not the usual "supply side" response commonly discussed today. No additional factors of production are brought forth. Rather it reflects a transfer of resources from favored activities to the taxpayer and the government. The actual welfare change is ambiguous.

Table 4.2 shows that a further reduction of tax rates to a statutory limit of 50 percent will be a revenue raiser if the full avoidance repsonse occurs. The labor supply response is relatively small. In the no-avoidance case an additional 600 million may be raised, or $\$ 1.2$ billion additional earned. The reduction in the top rate to 50 percent will largely affect non-labor income. A negative income effect on labor supply will therefore substantially offset the extra effort produced by the reduction in the earned income rate. If a capital 


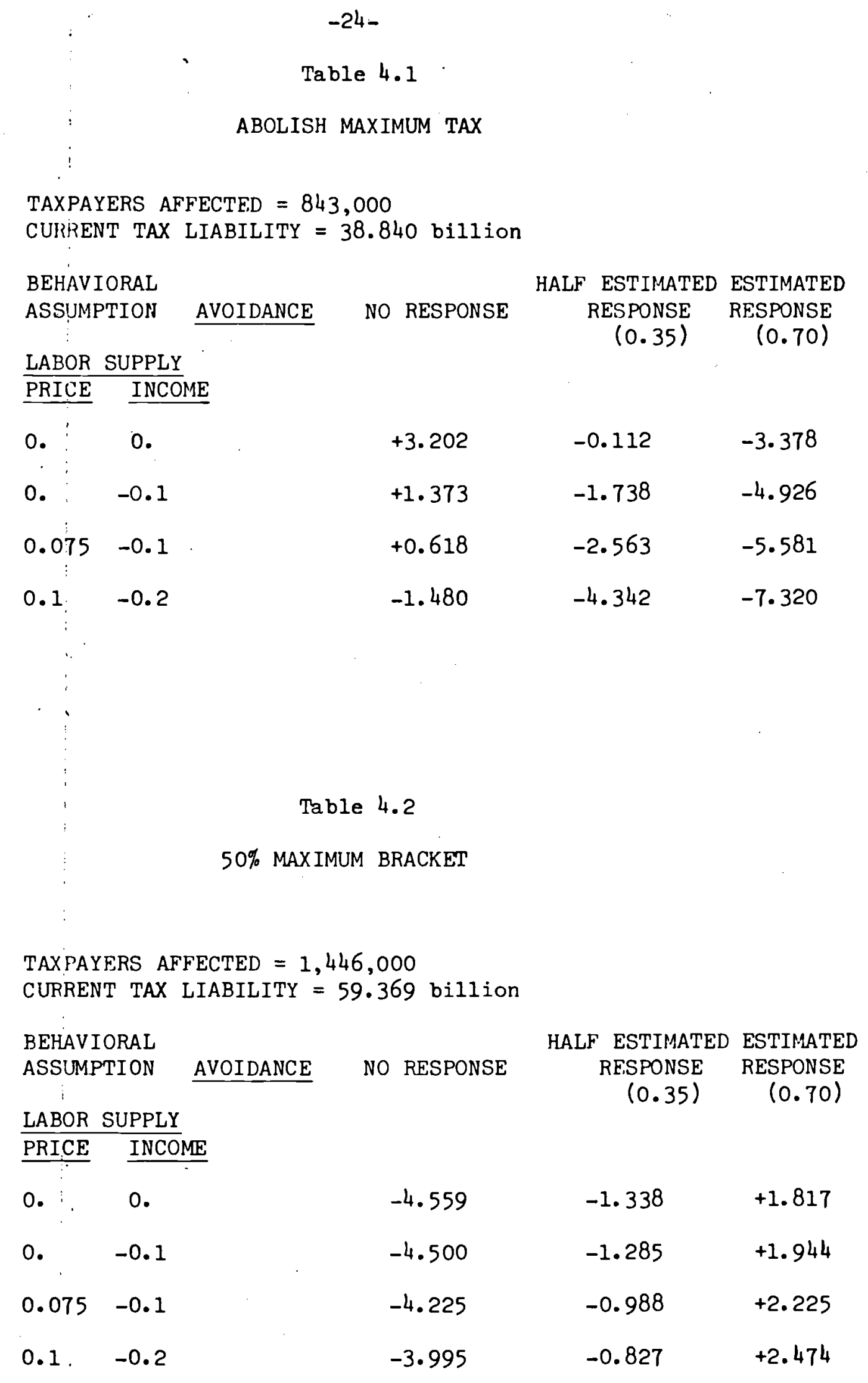




$$
\begin{gathered}
-25- \\
\text { Table } 4.3
\end{gathered}
$$

APPLY DEDUCTIONS TO UNEARNED INCOME

TAXPAYFRS AFFECTED $=1,323,000$

CURRENT TAX LIABILITY $=59.447$ billion

BEHAVIORAL

ASSUIYPTION
AVOIDANCE NO RESPONSE

$$
\begin{array}{cc}
\text { HALF ESTIMATED } & \text { ESTIMATED } \\
\text { RESPONSE } & \text { RESPONSE } \\
(0.35) & (0.70)
\end{array}
$$

LABOR SUPPLY

PRICE INCOME
0.
0.
$-2.608$
$-2.246$
$-1.856$
0.
$-0.1$
$-2.546$
$-2.228$
$-1.783$
$0.075-0.1$
$-2.289$
$-1.991$
$-1.538$
$0.1:-0.2$
$-2.099$
$-1.867$
$-1.357$

Table 4.4

APPLY DEDUCTIONS TO EARNED INCOME

TAXPAYERS AFFECTED $=1,168,000$

CURRENT TAX LIABILITY $=47.596$ billion

BEHAV IORAL

ASSUMPTION

AVOIDANCE NO RESPONSE
HALF ESTIMATED ESTIMATED RESPONSE RESPONSE
$(0.35) \quad(0.70)$

\section{LABOR SUPPLY}

\section{PRICE INCOME}
0.
0.
$-1.645$
$-0.070$
$+1.399$
$0 . \quad-0.1$
$-1.552$
$-0.023$
$+1.499$
$0.075-0.1$
$-1.340$
$+0.193$
$+1.730$
$0.1-0.2$
$-1.145$
$+0.309$
$+1.941$ 
income response is also included an additional revenue increase of roughly one third the order of magnitude of the current Maximum Tax will result. The revenue cost of a 50 percent maximum rate is therefore overstated by this simulation by 1 to 2 billion if one assumes that capital income will respond in a similar fashion as labor income.

Applying deductions to unearned income is likely to be a revenue loser. As the unearned tax rate may well be higher than the current average of earned and unearned rates, avoidance may well be even more attractive under this reform for many taxpayers. Even the maximum avoidance response will produce only 750 million as a revenue of $f$ set.

Applying deductions to earned income has two benefits from a revenue point of view. First, it is a less costly option even assuming no response. This is because current, avoidance partially offsets non-labor income under current rules. Under this option avoidance would reduce the tax liability by only the earned income marginal rate. Second, the behavioral response to avoidance would be greatest as the price of avoidance has been increase to 50 cents on the dollar. This will mean that a higher fraction of income will be subject to tax. In conclusion, it is likely that a reduction or reform of the upper brackets of the tax rate schedule would be relatively costless or might even increase tax revenues. However, a majority of the revenue offset from a behavioral response does not come from an increase in factor supply. Rather it is a pecuniary gain to the government and taxpayers as a result of less expenditure on tax avoidance. The high labor supply elasticities used in many supply side models of the economy may exaggerate the benefits of a tax rate reduction. However, the neglect of the avoidance response by any model produces a serious overestimate of the revenue cost of marginal rate reductions. 


\section{Footnotes}

${ }^{1}$ See Lindsey, Is the Maximum Tax on Earned Income Effective?, NBER Working Paper No. 613.

2 Taxpayers who are married Filing Separately or who income average are ineligible for the Maximum Tax. Furthermore, in order to qualify the taxpayer must have Earned Taxable Income at least as great as the 50 percent bracket amount, $\$ 60,000$ for married taxpayers, $\$ 41,700$ for single taxpayers.

${ }^{3}$ The definition of Earned Taxable Income is:

$$
\text { ETI }=\frac{\text { PSINC }}{\text { AGI }} \times \text { TAXINC }- \text { PREF }
$$




\title{
References
}

\begin{abstract}
Auerbach and Rosen, Will the Real Excess Burden Please Stand UP?, NBER Working Paper no. 495.
\end{abstract}

Burtless, G. and Hausman, J., "The Effect of Taxation on Labor Supply: Evaluating the Gary Negative Income Tax Experiment", Journal of Political Economy, 1978, vol. 86, no. 6.

Feenberg, Personal Communication

Feenberg and Rosen, Alternative Tax Treatment of the Family: Simulation Methodology and Results, NBER Working Paper No. 497.

Fullerton, On the Possibility of an Inverse Relationship Between Tax Rates and Government Revenues.
Hausman (1979), "The Effect of Taxes on Labor Supply", Forthcoming in Aaron and Pechman, The Effect of Taxes on Economic Activity.
Kahn, Harry, "Personal Deductions in Federal Income Tax". (National Bureau of Economic Research: Fiscal Studies No. 6) Princeton: Princeton University Press, 1960.

Lindsey, Lawrence, Is the Maximum Tax on Earned Income Effective?, NBER Working Paper No. 613.

Yitzhaki, Personal Taxation Incentives and Tax Reform (unpublished). 